\section{Education and development for entrepreneurs in the canton of Atacames}

Educación y desarrollo a emprendedores del cantón Atacames

\section{Emma Angelina Salazar Tuarez *}

\section{ABSTRACT}

Accounting and tax education provides the necessary knowledge for the development of entrepreneurs. In this sense, this research was oriented to analyze the fulfillment of accounting and tax duties in order to describe the needs required to strengthen the tax education of entrepreneurs in the parish of Atacames canton. Methodologically it is a descriptive study, with an exploratory scope, using a sample of 296 entrepreneurs surveyed and a review of the tax regime for microenterprises. As a result of the characterization of the entrepreneurs, all of them are not registered with the Internal Revenue Service; the largest number of entrepreneurs have Ruc, they are not required to keep accounting records, the type of business is commercial, the time in operation is more than four years, they did not know about tax laws, they do not keep records of income and expenses, a few have workers in their business, a minimum number of workers are affiliated to social security. In conclusion, the entrepreneurs were interested in receiving training in accounting and tax issues, in addition to learning about tax regulations to comply with their tax obligations.

Keywords: Education and development, accountant, taxation, entrepreneur.

\footnotetext{
* Master in Business Administration, Universidad Técnica Luis Vargas Torres de Esmeraldas, emma.salazar@utelvt.edu.ec, https://orcid.org/0000-00018689-7274
}

JOURNAL OF BUSINESS and entrepreneurial studies

ISSN: 2576-097|

Atribución/Reconocimiento-NoCo mercial- Compartirlgual 4.0 Licencia Pública Internacional — CC

BY-NC-SA 4.0

https://creativecommons.org/licenses /by-nc- sa/4.0/legalcode.es

Journal of Business and entrepreneurial January - March Vol. 6 - I - 2022 http://journalbusinesses.com/index.php/revista e-ISSN: 2576-097I

journalbusinessentrepreneurial@gmail.com Receipt: II Febrary 202 I

Approval: 23 July 2021

Page 79-93 


\section{RESUMEN}

La educación contable y tributaria facilita los conocimientos necesarios para el desarrollo de los emprendedores. En este sentido, la presente investigación se orientó analizar el cumplimiento de los deberes contables y tributarios con la finalidad de describir las necesidades que requerían para fortalecer la educación tributaria de los emprendedores de la parroquia del cantón Atacames. Metodológicamente es un estudio descriptivo, con un alcance exploratorio, se utilizó una muestra de 296 emprendedores encuestados y una revisión del régimen impositivo para microempresas. Como resultado en la caracterización de los emprendedores todos no están registrados en el Servicios de Rentas Internas; el mayor número de emprendedores tiene Ruc, no están obligados a llevar contabilidad, el tipo de negocio es comercial, el tiempo funcionando más de cuatro años, desconocían sobre leyes tributarias, no llevan registro de ingresos y egresos, unos pocos cuentan con trabajadores en su negocio, una cantidad mínima de los trabajadores están afiliados al seguro social. En conclusión, los emprendedores estuvieron interesados en recibir capacitaciones en temas contable y tributario, además de conocer la normativa tributaria para el cumplimiento de sus deberes tributarios.

Palabras clave: Educación y desarrollo, contable, tributación, empresario.

\section{INTRODUCTION}

Education and accounting development for entrepreneurs to strengthen their tax knowledge, in order to enable them to comply with their formal duties with the tax administration, aimed at providing training, technical advice, support and follow-up to entrepreneurs and traders on accounting and tax issues, for the proper development of their business activities.

The main difficulties identified for the formalization of micro-entrepreneurs' businesses are due to the fact that they do not record economic facts, have poor inventory management and are unaware of the real consequences of a labor lawsuit. (Jaramillo et al., 2020, p 167).

According to reports from international organizations such as the World Bank, microenterprises are currently becoming important economic actors in promoting the development of the communities to which they belong, since they generate between 40 and 60 percent of self-employment. It is said that a large number of the population emerges from poverty, obtains a better quality of life and guarantees their employment, thanks to the profits from this type of business. (Mendoza et al., 2020, p.32).

In general terms, comprehensive business formalization is beneficial for microentrepreneurs because it improves their productive potential, stimulates innovation capacity, solves existing problems or needs, prevents penalties and early closure of companies, becoming a vital tool to increase competitiveness and business permanence over time. (Jaramillo et al., 2020, p. 56).

Based on the above considerations, according to Toscano et al., (2020) the state, businessmen and entrepreneurs generate the most jobs in an economy. 
Therefore, it is necessary to point out that according to Ecuador's tax regulations, individuals who are not required to keep accounting records, which are required to have a RUC but not to keep full accounting records, according to the tax law until March 2015 , these people were considered as informal workers, although they are not required to keep full accounting records, but by having a RUC they must comply with other obligations such as keeping records of income and expenses, an action that allows to show accounts of the economic activity of the individual. (Toscano et al., 2020, p. 45). The objective of the research is to analyze compliance with accounting and tax duties in order to describe the needs required to strengthen knowledge with training in tax education for entrepreneurs in the canton of Atacames. From the constructivist paradigm, a quantitative and qualitative approach; according to the type of study the research has a descriptive methodological design with exploratory scope, the techniques used were survey, direct observation and documentary review. For this purpose, 296 surveys were applied to entrepreneurs; visits were made to the different enterprises to verify the management of accounting and tax information; a documentary review of the tax regime for microenterprises in Ecuador, to subsequently provide technical advice, accompaniment and follow-up to entrepreneurs and traders in accounting and tax aspects, which allow the proper development of their commercial and productive activities; as well as compliance with tax obligations. In addition, to strengthen entrepreneurs and merchants through a continuous process of training and theoretical and practical education, which will enable them to improve their organizational, accounting and tax procedures. As a result, most of the merchants required knowledge in accounting and tax matters. It should be noted that the training and theoreticalpractical training to entrepreneurs were given from November 16 to December 20, 2020.

This study is the result of the project "Training and accounting and tax advice to entrepreneurs and traders in the parishes of the cantons of Esmeraldas and Atacames in the province of Esmeraldas (stage 2)". The research allows describing the profile of the entrepreneurs of the parish of Atacames canton, with reference to the level of tax education they need for the development of their organizational, accounting and tax procedures.

Education "is a permanent process that enables the development of the potential of the human being in a comprehensive manner", where higher education institutions in commitment to this law must develop learning strategies that enhance and transmit knowledge, to prepare students in the exercise of the profession or discipline. (Rodríguez et al., 2020, p. 56)

For González (202I) The tax education programs will consist of a set of measures aimed at stimulating the level of tax morale of the country's taxpayers. In addition, he points out that the main problem in taxation is the lack of citizen awareness at the time of paying taxes. According to Morán, et al, (2016) cited in (Morales, 2019) in Ecuador it can be analyzed that there is a deep link between the organization and the stakeholders as generators of economic, social, cultural and environmental development; this in turn 
has allowed to undoubtedly improve lifestyles and build a dignified, healthy and progressive society in the country.

The search for evidence Flores (202I) among its main objectives is the search to increase civic awareness, both students and citizens to comply with their fiscal and tax obligations; in a timely and voluntary manner. In this perspective, Flores, (202I) when investigating the strategies worked from the NAFs (project of linkage with the community: Núcleo de Apoyo Fiscal y Tributario) and the Academy, state that the results obtained allow concluding that in order to promote tax culture, a joint work between the tax administration, the academy and society is required.

In Ecuador, in order to face the obstacle of lack of knowledge, the academy contributes with the business sector, considering that according to Armijos (2017) cited in (Morales, 2019) the academic sector should take advantage of this relationship to develop its teaching, research and linkage functions with the community.

As it points out Polaino \& Romillo, (2017) in Ecuador has been conceptualized as linking the university with society, it is one of the substantive functions of higher education that, together with academic training and research, has the purpose of solving community problems, through projects, pre-professional internships, training and other professional services, which enable communication and effective interaction of the university with its environment, as well as the integration of theory with the practice of university work in terms of sustainable social development.

Currently, in the Ecuadorian context, tax collection is considered a primary activity to generate income according to Velepucha et al. (202I) cited in Nacata \& Monge, (202I), with the purpose of covering the needs of the population to contribute to its development.

It should be taken into account that a problem of great interest in the field of the deduction regime and tax evasion, which often harm the growth and development of the companies, as well as the country, since it affects the businessman who is formalized and pays his taxes; the objective was to determine if the effects of the deduction regime affect tax evasion in the service sector. (Ruiz et al., 202I, p. 43).

As stated in art. 284 of the Political Constitution of the Republic of Ecuador Paredes \& García (202I) Art. 284 of the Political Constitution of the Republic of Ecuador states that economic policy will have the following objectives aligned with tax collection:

- Ensure an adequate distribution of income and national wealth.

- To achieve a balanced development of the national territory, integration between regions, in the countryside, between the countryside and the city, economically, socially and culturally.

The primary objective of tax education is to transmit ideas, values and attitudes in favor of tax responsibility and against fraudulent behavior.... (Liler, 20I5, p. 56).

The entrepreneur is the subject capable of taking risks and whose behavior is one of the reasons why the market is in constant movement. 
Mendoza et al. (2020). On the other hand, according to Formichella, (2004) quoted in (Espinoza \& Espinoza, 2020) an entrepreneurial person is capable of creating, carrying out his ideas, generating goods and services, assuming risks and facing problems; in addition, he is an individual who sees opportunities in his environment, and with initiative manages to create the structure he needs to undertake his project.

According to data available from the Global Entrepreneuship Monitor, Ecuador as of 2017, had the highest rate of early entrepreneurial activity in the region (Espinoza \& Espinoza, 2020).

It should be noted that for Amores \& Castillo, (20I7) cited in (Andrade et al., 202I) in Ecuador there is a nourished business mass that reveals the reality of the companies that generate more contribution to the GDP, which are not micro enterprises; with a participation of around 22,700 establishments that generate $76 \%$ of the sales at national level, this allows evidencing the permanence with which the micro business sector has in the market.

It is appropriate to mention Peña (202I) which deals with the study of Tax Awareness as an alternative to non-compliance with tax obligations by businessmen, mostly entrepreneurs who, despite having formalized their businesses, are immersed in informality.

In this sense, we can see that it is necessary to have tax education to generate awareness and, therefore, tax culture so that citizens and, especially, informal entrepreneurs, do not commit tax crimes and, therefore, we can understand that taxes are resources collected by the State as administrator, but in reality these resources will be redistributed to the population in the provision of public services (such as hospitals, schools, universities).(Peña, 202I, p. 432).

Linked to the concept, said with the words of Mendoza et al., (2016) concludes that it is necessary to basically or substantially alter our tax structures and, with them as a primordial element thereof, the fiscal moral conscience of individuals, it will be necessary to descend from the beautiful path of theorizations and undertake a more thankless, but also more necessary and direct task: that of carrying out a broad educational work that produces those effects and thus raises the absolute and general value of our fiscal morality.

In the opinion of Rojas \& Romero, (2017) companies that innovate or create value with new ideas for products or services and develop a serious administrative process with sustainable development are the ones that will manage to remain in the future.

The State seeks that taxpayers comply with their tax obligations, for this reason the former President of the Republic, Lenín Moreno, proposed the creation of the so-called Organic Law of Simplicity and Tax Progressivity. This law was published on December 3I, 2019 through the First Supplement to the Official Gazette No. I I I, and contains the new Tax Regime for Micro-enterprises. (Balón, 202I, p. 345).

As a complement, the Tax Regime for Micro-companies is a mandatory regime, applicable to income, value added and special consumption taxes for micro-companies, including entrepreneurs that comply with the condition of micro-companies as 
established in the Organic Code of Production, Commerce and Investments (COPCl) and the corresponding Regulation, as long as they do not fall within the limitations established in the regulation. (Bonín et al., 202I, p. 34).

In relation to this concept, it is worth mentioning that the new tax regime for microenterprises Espinoza \& Espinoza (2020) that the new tax regime for microenterprises came into force on February 13 of this year with the purpose of facilitating the formalization of enterprises, however, a $2 \%$ sales tax represents a factor against entrepreneurs because this is a percentage that goes on their income, regardless of whether they generate profit or not. This represents a constant threat and a barrier when considering legalization.

And in the same way, the Law of Simplification and Progressivity of Taxation (2019) in its article 97.17 establishes that taxpayers considered as such, including entrepreneurs that comply with the condition of micro-enterprises, will be subject to the tax regime for micro-enterprises (Lluvichusca-Guaman et al., 202I, p.23I).

The Internal Revenue Service (SRI) issues by resolution lists of cadastres and obligations to be fulfilled by taxpayers included in the tax regime for micro-enterprises, in addition the same control entity is in charge of updating the Single Taxpayers Registry (RUC) with the information of micro-enterprises. (Boada-Martillo et al., 2021, p. 67)

As it expresses Yanza (202I) in comparison to the previous general regime to which microentrepreneurs belonged, was the change regarding the payment of income tax within their tax obligations that the Tax Simplification and Progressivity Law placed, since the change from previously contributing $22 \%$ income tax on their net profits and also being able to deduct their costs and expenses, to now paying $2 \%$ tax on their income, was controversial and in disagreement for those who were included by the IRS in this regime considering the significant losses that many microentrepreneurs have had due to the pandemic.

In a similar way Camino \& Florencia (202I) I found with the micro-entrepreneurs that the laws and tax reforms issued by the national government to legalize the activities of the enterprises developed in Ecuador and formalize the tax obligations to be met from 2018 to 2020, it was evident that these laws in 2018 had an effect of benefiting the entrepreneur, but in 2020 due to the low sales caused by the measures adopted by the pandemic of covid-19 and the change in the way of paying income tax, they do not feel benefited, because before they calculated and paid this tax on profits and now it is done on the basis of $2 \%$ of gross sales.

Analyzes Jimenez (2015) that this new regime has had a great impact on the accounting area, thus directly affecting very important accounts to be covered, this shows a failure in the regulations since its main objective is to support the economic part of the company.

\section{MATERIALS AND METHODS}

Based on Mendoza \& Ramírez (2020) constructivist paradigm, with a quantitative and qualitative approach; according to the analysis and scope the type of research study has 
a descriptive methodological design with an exploratory level. According to Ferreiro (2017) the collection instruments to be used is the survey technique and direct observation; it should be added that the questionnaire structured by twelve questions, applied to a sample composed of 296 respondents, from the sector of entrepreneurs located within the Atacames canton of the province of Esmeraldas - Ecuador, specifically in the parishes Tonchigue, Tonsupa, Súa, Same, Atacames; plus visits to different businesses to verify the management of accounting and tax information, documentary review of articles of the tax regime for microenterprises and the web portal of the Internal Revenue Service (SRI) of Ecuador. training given from November 16 to December 20, 2020.

It should be added that the research involves the participation of students as surveyors, advisors, and facilitators in the training given; and the accompaniment of teachers and tutors from the Universidad Técnica Luis Vargas Torres de Esmeraldas (UTLVTE), specifically from the careers of foreign trade, accounting and auditing, administration, tourism and social work.

\section{RESULTS}

Regarding the results obtained from the surveys, what type of tax registration do you use? 49.2\% have the Single Taxpayer Registry (RUC), 25.1\% are in the Ecuadorian Simplified Tax System (RISE), and $25.8 \%$ have economic activity without being legally registered with the Internal Revenue Service. In addition, what type of taxpayers? results; according to those registered with RUC 74.9\% are not obliged to keep accounting, $23.1 \%$ are obliged to keep accounting, and $2 \%$ are companies/special taxpayers. On the other hand, what type of business is it? according to the activity; $61.6 \%$ are engaged in commercial activity, $35.4 \%$ in services, $3 \%$ in industrial activities. Likewise, How long has the business been in operation, in relation to the years in activity; $39 \%$ are businesses of 4 years or more, $31.5 \%$ are from I to 3 years, $29.5 \%$ are businesses of less than I year.

Another point is the answers to the dichotomous questions (Table I); regarding the economic activity registered with the Internal Revenue Service (SRI) 66.8\% said Yes and $32.2 \%$ said No; in the case of knowledge of the tax laws in force in the country, $45.9 \%$ said Yes and $54.1 \%$ said No; hence, those who said they keep their income and expenditure records $49 \%$ said Yes and $51 \%$ said No; therefore, those who have workers $26.8 \%$ said $Y$ es and $73.2 \%$ said No; considering those who indicate that they have workers affiliated to the Ecuadorian Institute of Social Security (IESS), $10.6 \%$ said Yes and $89.4 \%$ said No; as shown in the table, $28.9 \%$ said Yes and $71.1 \%$ said No; as shown in the table, have they received training in tax or business matters? $73 \%$ said that they would like to receive training and $27 \%$ said Yes and $27 \%$ said No; they would also like a UTLVTE student to accompany them in their activities such as inventories, invoicing, income, expenses and declarations. $64.5 \%$ said $Y e s$ and $35.5 \%$ said table I 
Table I. Questions

Dichotomous questions

YES NO

$\% \%$

Is your economic activity registered with the Servicio de Rentas $\quad 66,8 \quad 32,2$ Internas SRI (Internal Revenue Service)?

Do you have knowledge of the tax laws in force in the country? $45,9 \quad 54, I$

Do you keep a record of your income and expenses?

Do you have employees?

$49 \quad 51$

Are workers affiliated to IESS?

$26,8 \quad 73,2$

Have you received tax or business training?

$10,6 \quad 89,4$

Would you like to receive training?

$28,97 \mathrm{I}, \mathrm{I}$

Would you like a UTLVTE student to accompany you in your $64,5 \quad 35,5$ activities such as inventories, invoicing, receipts, disbursements and declarations?

Own elaboration

Note: Survey of entrepreneurs and merchants in the canton of Atacames.

This shows that most of the entrepreneurs surveyed require training; therefore, $90 \%$ of the entrepreneurs agreed to receive training. Regarding individual counseling, it was observed in the visits to the commercial premises that taxpayers registered with the IRS do not keep accounting records of the income and expenses of their businesses. Taking into account the response of the entrepreneurs' adaptation, it would be necessary to provide specific information to each beneficiary according to their needs. Due to the lack of knowledge of the tax laws in force in the country, they prefer not to register with the SRI.

The Single Taxpayers Registry is an instrument whose function is to register and identify taxpayers for tax purposes and provide this information to the Tax Administration. It is used to carry out any economic activity permanently or occasionally in Ecuador. It corresponds to the identification number assigned to all those natural persons and/or companies that are holders of goods or rights for which they must pay taxes.(Registro Único de Contribuyentes (RUC) - Intersri - Servicio de Rentas Internas, n.d.)

Individuals, corporations and entrepreneurs that meet the conditions of microenterprises as provided in the Organic Code of Production, Commerce and Investments and the corresponding Regulations, provided they are not within the limitations to the regime. For the categorization of micro-enterprises, those taxpayers with gross income of up to three hundred thousand United States of America dollars (USD. 300,000) and that at the date of generation of the registration have up to nine (9) workers shall be considered. For such categorization, the amount of income shall prevail over the number of workers.(Servicio de Rentas Internas, 2020).

Informs that taxpayers subject to the (SRI, 2020) that taxpayers subject to the Tax Regime for Micro-enterprises must comply with the formal and material duties as 
provided in the tax regulations in force. Failure to comply will be sanctioned in accordance with the law, these are:

As stated (SRI, 2020) the Tax Regime for Micro-companies applies to income, value added and special consumption taxes, therefore, taxes not defined for this regime must be declared in the form and means defined by the corresponding tax law and its implementing regulations. The following is a summary of the form of filing tax obligations for taxpayers subject to the tax regime for micro-enterprises:

Table 2. Presentation of tax obligations for taxpayers subject to the tax regime for microenterprises

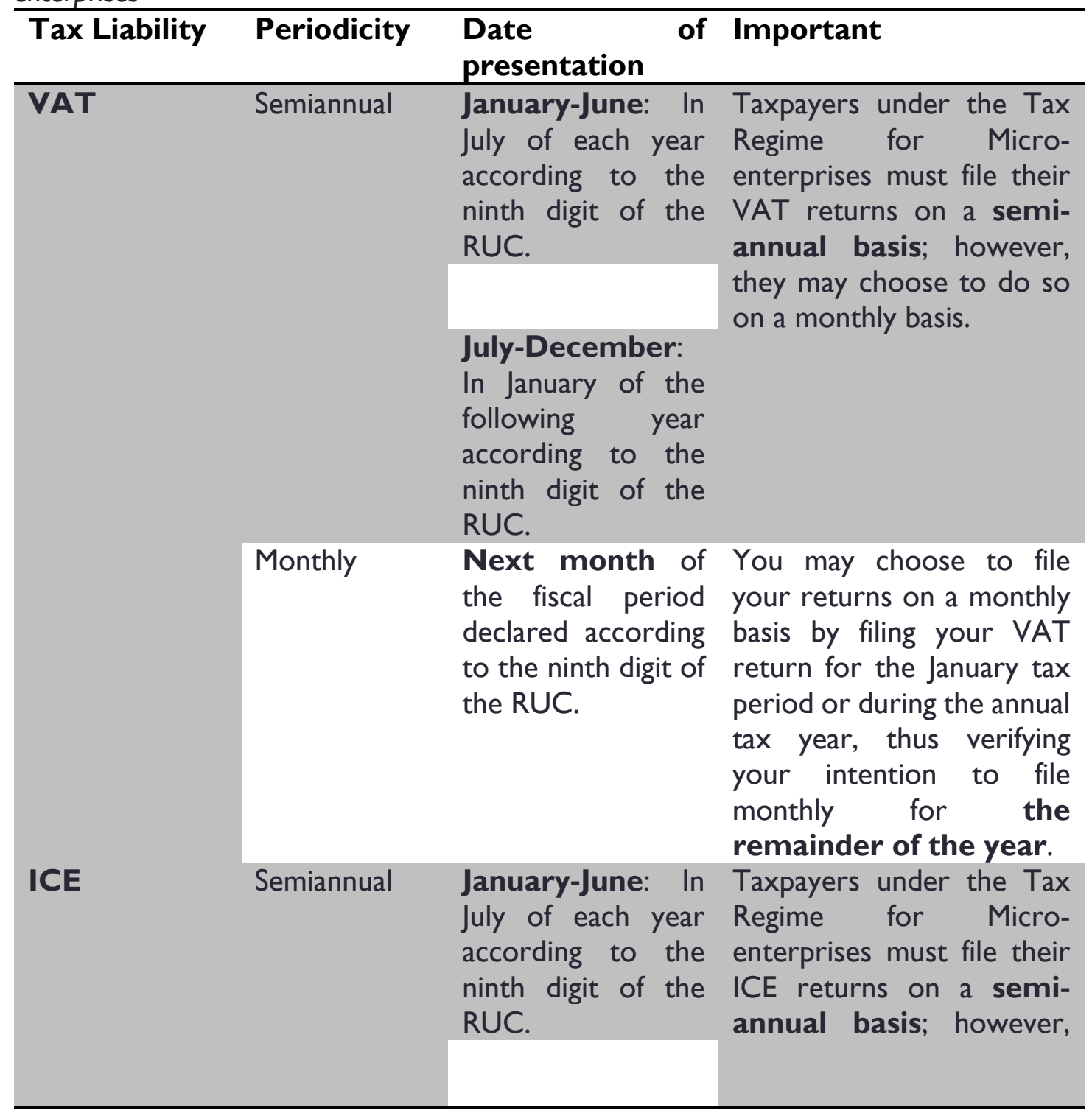




\begin{tabular}{|c|c|c|c|}
\hline & & $\begin{array}{l}\text { July-December: } \\
\text { In January of the } \\
\text { following year } \\
\text { according to the } \\
\text { ninth digit of the } \\
\text { RUC. }\end{array}$ & $\begin{array}{l}\text { they may choose to do so } \\
\text { on a monthly basis. }\end{array}$ \\
\hline & Monthly & $\begin{array}{l}\text { Next month of } \\
\text { the fiscal period } \\
\text { declared according } \\
\text { to the ninth digit of } \\
\text { the RUC. }\end{array}$ & $\begin{array}{l}\text { You may choose to file } \\
\text { your returns on a monthly } \\
\text { basis by filing your ICE } \\
\text { return for the January tax } \\
\text { period or during the annual } \\
\text { tax year, which will verify } \\
\text { your intention to file on a } \\
\text { monthly basis for the rest } \\
\text { of the year. }\end{array}$ \\
\hline \multirow[t]{4}{*}{ Income Tax } & Semiannual & $\begin{array}{l}\text { January-June: In } \\
\text { July of each year } \\
\text { according to the } \\
\text { ninth digit of the } \\
\text { RUC. }\end{array}$ & $\begin{array}{l}\text { Taxpayers under the Tax } \\
\text { Regime for Micro- } \\
\text { enterprises must file the } \\
\text { income tax return on a } \\
\text { semi-annual basis, even } \\
\text { when the taxpayer has } \\
\text { selected the monthly VAT } \\
\text { return. }\end{array}$ \\
\hline & & $\begin{array}{l}\text { July-December: } \\
\text { In January of the } \\
\text { following year } \\
\text { according to the } \\
\text { ninth digit of the } \\
\text { RUC. }\end{array}$ & $\begin{array}{l}\text { It shall be filed even in cases } \\
\text { where the taxpayer has not } \\
\text { obtained income related to } \\
\text { the Tax Regime for Micro- } \\
\text { enterprises, in which case } \\
\text { the return shall be } \\
\text { informative. }\end{array}$ \\
\hline & Annual & $\begin{array}{l}\text { Natural person: } \\
\text { until March of the } \\
\text { following fiscal } \\
\text { year. }\end{array}$ & It is mandatory for: \\
\hline & & $\begin{array}{l}\text { Companies: until } \\
\text { April of the } \\
\text { following fiscal year }\end{array}$ & $\begin{array}{l}\text { I. Companies and } \\
\text { permanent establishments } \\
\text { of non-resident companies, } \\
\text { in all cases. }\end{array}$ \\
\hline
\end{tabular}




\begin{tabular}{|c|c|c|c|}
\hline \multirow{4}{*}{$\begin{array}{l}\text { Income tax } \\
\text { withholdings } \\
\text { at source }\end{array}$} & \multirow{4}{*}{ Semiannual } & & $\begin{array}{l}\text { 2. Individuals who obtain } \\
\text { income from other sources } \\
\text { in addition to the business } \\
\text { activity subject to the Tax } \\
\text { Regime for Micro- } \\
\text { enterprises. }\end{array}$ \\
\hline & & & $\begin{array}{l}\text { 3. Individuals who need to } \\
\text { request an overpayment or } \\
\text { file a claim for undue } \\
\text { payment of income tax. }\end{array}$ \\
\hline & & $\begin{array}{l}\text { January-June: In } \\
\text { July of each year } \\
\text { according to the } \\
\text { ninth digit of the } \\
\text { RUC. }\end{array}$ & $\begin{array}{l}\text { The semiannual return } \\
\text { shall be filed even when the } \\
\text { taxpayer has been qualified } \\
\text { as a withholding agent or } \\
\text { special taxpayer. }\end{array}$ \\
\hline & & $\begin{array}{l}\text { July-December: } \\
\text { In January of the } \\
\text { following year } \\
\text { according to the } \\
\text { ninth digit of the } \\
\text { RUC. }\end{array}$ & $\begin{array}{l}\text { In those cases in which the } \\
\text { taxpayer has not made } \\
\text { withholdings, he/she shall } \\
\text { not file the respective } \\
\text { return. }\end{array}$ \\
\hline \multirow[t]{3}{*}{$\begin{array}{l}\text { Simplified } \\
\text { Transactional } \\
\text { Schedule } \\
\text { (ATS) }\end{array}$} & \multirow[t]{2}{*}{ Semiannual } & $\begin{array}{l}\text { January-June: In } \\
\text { August of each year } \\
\text { according to the } \\
\text { ninth digit of the } \\
\text { RUC. }\end{array}$ & \multirow[t]{2}{*}{$\begin{array}{l}\text { If the taxpayer files the } \\
\text { VAT return on a semi- } \\
\text { annual basis the ATS must } \\
\text { be filed on a semi-annual } \\
\text { basis. }\end{array}$} \\
\hline & & $\begin{array}{l}\text { July-December: } \\
\text { In February of the } \\
\text { following year } \\
\text { according to the } \\
\text { ninth digit of the } \\
\text { RUC. }\end{array}$ & \\
\hline & Monthly & $\begin{array}{l}\text { Subsequent } \\
\text { month of the fiscal } \\
\text { period declared }\end{array}$ & $\begin{array}{l}\text { If the taxpayer files the } \\
\text { VAT return on a monthly }\end{array}$ \\
\hline
\end{tabular}




\begin{tabular}{ll}
\hline Annex ICE Semiannual & $\begin{array}{l}\text { according to the basis the ATS must be filed } \\
\text { ninth digit of the on a monthly basis. } \\
\text { RUC. }\end{array}$ \\
January-June: In If the taxpayer files the ECI \\
August of each year return on a semi-annual \\
according to the basis, Schedule ECl must be \\
ninth digit of the filed on a semi-annual basis. \\
RUC. \\
July-December: \\
In February of the \\
following year \\
according to the \\
ninth digit of the \\
RUC. \\
Next month of If the taxpayer files the ECI \\
the fiscal period return on a monthly basis, \\
declared according Schedule ECI must be filed \\
to the ninth digit of on a monthly basis. \\
the RUC.
\end{tabular}

Source (SRI, 2020)

Emphasizes (Servicio de Rentas Internas, 2020) that if you carry out an activity subject to the micro-enterprise regime and an activity that is within the limitations, you must remain in the Micro-enterprise Tax Regime and comply with the formal duties according to the conditions and form provided for taxpayers subject to this regime; nevertheless, it should be considered as Tax Regime for Micro-enterprises that at the moment of determining the Income Tax only the income coming from the economic activity that is subject to the Tax Regime for Micro-enterprises is subject to the $2 \%$ Income Tax rate, the rest of the income will be subject to Income Tax according to the conditions of the general regime.

It should be noted that (Servicio de Rentas Internas, 2020) states that individuals who had been previously included in the Tax Regime for Micro-enterprises may not be included in the RISE.

In relation to the profile of entrepreneurs in the parishes of Atacames canton, the surveys allow describing a considerable percentage of entrepreneurs who are registered with the SRI, mostly with RUC, as well as RISE; it is likely that the number of unregistered entrepreneurs, with the trainings received as mentioned by Armijos (2017) cited in Morales (2019) take advantage of the contribution of the academy decide to legalize their economic activity by registering with the SRI. Although Espinoza \& Espinoza (2020) 
consider that the new tax regime for microenterprises means a constant threat and a barrier when considering legalizing, as it refers to a $2 \%$ tax on sales which they consider represents for entrepreneurs a factor against them because this is a percentage that goes on their income, regardless of whether they generate profit or not. Moving on to another aspect, in order for entrepreneurs to comply with the formal duty to keep accounting or a record of income and expenses (Figure 4), as Peña (202I) states, it is necessary to have tax education to generate tax awareness and culture.

In another sense, as can be seen in (table I) the enterprises may not be generating labor spaces for the employability of the population of the canton, likewise there is evidence of a small number of workers affiliated to social security, contrasting with what is cited by Morán, et al, (2016) cited in Morales (2019) that in Ecuador there is a deep link between the organization and stakeholders as generators of economic development, to undoubtedly improve lifestyles and build a dignified, healthy and progressive society in the country.

\section{CONCLUSIONS}

Concluding in the process of the study allowed to observe in some cases absence and inconsistencies in terms of income and expenditure records, it has been possible to establish the importance of knowledge in accounting and tax education, which allows the business development of entrepreneurs in the parishes of the Canton Atacames.

Finally, once the training was given, it is worth mentioning the collaboration, commitment and interest of the beneficiary entrepreneurs, which allowed the students of the Universidad Técnica Luis Vargas Torres de Esmeradas (UTLVTE) to provide onsite advice, support and follow-up on the accounting and tax aspects of their businesses. It is worth mentioning that the education and development of entrepreneurs is the result of training in taxation and accounting for business development.

\section{REFERENCES}

Andrade, M., Giler M. , S., \& Castillo, F. (202I). Caja de ahorro y fomento una metodología para el financiamiento de los sectores microempresarios caso Quevedo-Ecuador. Revista Tecnológica Ciencia y Educación Edwards Deming, 5(2), 5560. https://doi.org/I0.37957/ed.v5i2.80. https://doi.org/I0.37957/ed.v5i2.80.

Balón, E. (202I). Impact of tax reforms of the tax regime for microenterprises. Peninsula Santa Elena State University.

Boada-Martillo, G., Vegara-Díaz, N., \& Concha-Ramírez, J. (2021). Impacto tributario provocado por el régimen impositivo para microempresas del sector comercial en el Ecuador Tax impact caused by the tax regime on micro-enterprises in the commercial sector in Ecuador Impacto fiscal causado pelo regime tributário sobre a. Polo Del Conocimiento, 6(6), 903-922. https://doi.org/10.23857/pc.v6i6.2794

Bonín, V., Vélez, E., \& Tapia, J. (202I). Income tax regime for microenterprises, right or wrong? Revista de Investigación Formativa; Innovación y Aplicaciones Técnico - 
Tecnológicas, 3(I), 7I-77.

Camino, M., \& Florencia, M. (2021). Analysis of tax reforms: Perspectives of incentives and regulations to entrepreneurship period 2018-2020. Graduate thesis, University of Guayaquil.

Espinoza, M. A., \& Espinoza, M. D. (2020). Entrepreneurship In Ecuador: A Bibliographical Review Of lts Current Situation. February. https://www.researchgate.net/profile/Marcos-Espinoza-3/publication/349/08465

Ferreiro, R. (2017). how to be a teacher researcher? the JAVI method- vademecum. Lideres Educativos Collection, 35(9). https://ebooks724.ezproxy.uniminuto.edu/onlinepdfjs/view.aspx

Flores, J. (2021). Linking with society : impact of the tax support core, in the generation of tax culture. Journal of Science and Research, 6, 93-108.

González, J. (202I). Tax culture and the factors that affect compliance with tax obligations of MSMEs in the canton of Daule. University of Guayaquil.

Jaramillo, P., Pérez, N., Polania, C., \& Villalba, W. (2020). Integral formalization for microentrepreneurs in Girardot and La Mesa. Jorunal of Business and Entrepreneurial Studies, 4(8).

Jimenez, C. (2015). Advantages and disadvantages of the application of the Tax Regime for Microenterprises, in MINIMARKET (food distributors) located in the Biloxi sector of the DMQ of the year 2020 [Universidad Politecnica Salesiana Sede Cuenca]. https://dspace.ups.edu.ec/bitstream/I 23456789/7986/I/UPS-CT004855.pdf

Liler, R. (2015). Tax education as a measure to increase tax collection in the city of Chota, 2013. 3(24) [Universidad Nacional de Cajamarca]. http://repositorio.unc.edu.pe/handle/UNC/7I 2

Lluvichusca-Guaman, J. T., Valdiviezo-Araujo, M. F., \& Soto-González, C. O. (202I). Ecuadorian companies. 593 Digital Publisher, 6, 326-335.

Mendoza, E., Villarroel, M., \& Carranza, W. (2020). Characterization of microenterprises in marginal urban sectors of Quevedo. Centrosur, 4(4), I-23. http://www.centrosureditorial.com/index.php/revista/article/view/40

Mendoza, F., Palomino, R., Robles, J., \& Ramírez, S. (2016). Correlation between tax culture and university tax education: case Sonora State University. Global Business Journal, 4(I), 6I-76. https://www.theibfr.com/wpfb-file/rgn-v4nI-20I6-5-pdf/. https://www.theibfr.com/wpfb-file/rgn-v4n I-2016-5-pdf/

Mendoza, A. O., \& Ramírez, J. M. (2020). Learning research methodology. In Editorial Grupo Compás.

Morales, E. L. A. (2019). Application of corporate social responsibility in Ecuadorian companies in the last decade | Centro Sur. In Centro Sur. http://www.centrosureditorial.com/index.php/revista/article/view/77/202

Nacata, H. M., \& Monge, J. F. (202I). Tax regime for microenterprises and its incidence in the calculation of income tax: DISPROALCEX S.A. case. Eruditus Magazine, 2(3), 29-40. https://doi.org/ 10.35290/re.v2n3.2021.507

Paredes, R. E., \& García, G. H. (202I). Tax culture as a strategy to reduce tax evasion in 
Ecuador. Eruditus Magazine, 2(I), 75-89. https://doi.org/ / 0.35290/re.v2n I.2021.390

Peña, L. (202I). Scenarios of tax evasion in Peru : The formation of tax awareness as an alternative. Sinergias Educativas, 0-3.

Polaino, C. J., \& Romillo, A. de J. (2017). Linking with society at the University of Otavalo, Ecuador. Formacion Universitaria, 10(3), 2I-30. https://doi.org//0.4067/S07/8500620I7000300004. https://doi.org/I0.4067/S07I8-500620I7000300004

Registro Único de Contribuyentes (RUC) - intersri - Servicio de Rentas Internas (Internal Revenue Service). (n.d.). Retrieved December I, 202I, from https://www.sri.gob.ec/ruc

Rodríguez, M., Trujillo, M., Salgar, C., \& Jaramillo, P. (2020). Accounting Laboratory: A didactic strategy for teaching the accounting cycle. 4(2I)-33.

Rojas, E., \& Romero, C. (2017). Reality of small associative enterprises in Sabana de Occidente*.

Perspectivas

https://revistas.uniminuto.edu/index.php/Pers/article/view/I58 I

Ruiz, G., Illa, G., Flores, F., \& Carrasco, P. (202I). Effects of the detraction regime on tax evasion by service sector firms in metropolitan Lima.

Internal Revenue Service. (2020). Régimen Impositivo Para Microempresas. Srinforma. https://www.sri.gob.ec/o/sri-portlet-biblioteca-alfrescointernet/descargar/c43fa8ba-ef9a-447c-b04b-0394afac642a/Enlace 4.pdf

SRI. (2020). Régimen Impositivo para Microempresas - intersri - Servicio de Rentas Internas. https://www.sri.gob.ec/regimen-impositivo-para-microempresas\#iqué-es.

Toscano, R., Vera, N., \& Carrera, F. (2020). Incidence of Underemployment in the Economy of Ecuadorian Families. Revista Tecnológica Ciencia y Educación Edwards Deming, 4(I). https://doi.org/I 0.37957/ed.v4il.45

Yanza, A. (2021). Effects of resolution No. NAC-DGERCGC20- 00000060 (article 9., Formal and material duties) of the Internal Revenue Service regarding the rules of the tax regime for micro-enterprises traders of medical supplies and medical services [Universidad Politécnica Salesiana]. https://emea.mitsubishielectric.com/ar/productssolutions/factory-automation/index.html 
